Ir has recently been reported that phycocyanin, a biliprotein found in the blue-green microalgae Spirulina, exerts anti-inflammatory effects in some animal models of inflammation. Taking into account these findings, we decided to elucidate whether phycocyanin might exert also inhibitory effects in the induced allergic inflammatory response and on histamine release from isolated rat mast cells. In in vivo experiments, phycocyanin $(100,200$ and $300 \mathrm{mg} / \mathrm{kg}$ post-orally (p.o.)) was administered $1 \mathrm{~h}$ before the challenge with $1 \mu \mathrm{g}$ of ovalbumin (OA) in the ear of mice previously sensitized with OA. One hour later, myeloperoxidase activity and ear edema were assessed. Phycocyanin significantly reduced both parameters. In separate experiments, phycocyanin (100 and $200 \mathrm{mg} / \mathrm{kg}$ p.o.) also reduced the blue spot area induced by intradermal injections of histamine, and the histamine releaser compound $48 / 80$ in rat skin. In concordance with the former results, phycocyanin also significantly reduced histamine release induced by compound $48 / 80$ from isolated peritoneal rat mast cells. The inhibitory effects of phycocyanin were dose dependent. Taken together, our results suggest that inhibition of allergic inflammatory response by phycocyanin is mediated, at least in part, by inhibition of histamine release from mast cells.

Key words: Phycocyanin, Inhibition, Histamine release, Allergic inflammatory response, Rat mast cells

\section{Role of histamine in the inhibitory effects of phycocyanin in experimental models of allergic inflammatory response}

\author{
D. Remirez, N. Ledón and R. González ${ }^{\mathrm{CA}}$
}

Ozone Research Center, National Center for Scientific Research, Post Box 6412, Havana, Cuba

${ }^{\mathrm{CA}}$ Corresponding Author

Fax: +537210233

E-mail: ozono@infomed.sld.cu

\section{Introduction}

We recently reported that phycocyanin, a biliprotein found in the blue-green microalgae Spirulina exerts antioxidative and anti-inflammatory effects in various in vitro and in vivo experimental models. ${ }^{1}$ These effects are mediated by the scavenging action of phycocyanin against reactive oxygen species (ROS) such as $\mathrm{OH}^{*}, \mathrm{RO}{ }^{*}$ and $\mathrm{RO}_{2}$, anti-lipoperoxidative activity, and inhibitory effects on prostaglandin and leukotriene biosynthesis. ${ }^{2,3}$ Recently, an inhibitory effect of Spirulina on mast cell-mediated immediatetype allergic reactions in rats has also been reported. ${ }^{4}$ Thus, taking into account the former findings and the fact that phycocyanin accounts for more than $20 \%$ of algae dry weight, we decided to elucidate whether or not both allergic inflammatory response and histamine release from rat mast cells are inhibited by phycocyanin.

\section{Materials and methods}

\section{Chemicals}

Ovalbumin, $o$-dianisidine and compound 48/80 were purchased from Sigma (St Louis, MO, USA).
Orthophthalaldehyde was obtained from Merck (Barcelona, Spain).

Other reagents of analytical grade were purchased from normal commercial sources.

\section{Preparation of phycocyanin extract}

Phycocyanin was extracted from microalgae Arthospira maxima as described in a Cuban patent. ${ }^{5}$ The blue powder thus obtained showed a peak in the visible absorption spectrum of $617 \mathrm{~nm}$, which is very close to that reported for c-phycocyanin. ${ }^{6}$

\section{Animals}

Male Balb/c mice (20-25g) and male SpragueDawley rats $(175-250 \mathrm{~g})$ were obtained from the breeding colony of the National Center for Laboratory Animal Production (CENPALAB, Havana, Cuba). The animals were housed under a $12 \mathrm{~h}$ light-dark cycle with room temperature maintained at $25^{\circ} \mathrm{C}$, humidity at $60 \%$, and food and water available ad libitum. The experiments were conducted in accordance with the ethical guidelines for investigations in laboratory animals and were approved by the Ethical Committee for Animal Experimentation of the National Center for Scientific Research. 


\section{Sensitization of mice and ear swelling} response to ovalbumin

This test was carried out as described by Hessel et $\mathrm{al}^{7}$ Active sensitization was performed by seven intraperitoneal injections of $10 \mu \mathrm{g}$ of ovalbumin in $0.5 \mathrm{ml}$ of saline on alternate days. A group of animals received injections with saline only.

Four weeks after the last injection, the mice were divided into groups of seven animals and treated by gavage with phycocyanin $(100,200$ and $300 \mathrm{mg} / \mathrm{kg})$, with triamcinolone $(10 \mathrm{mg} / \mathrm{kg})$ used as a reference drug or saline. One hour later, the animals were challenged intracutaneously with $1 \mu \mathrm{g}$ of ovalbumin in $0.01 \mathrm{ml}$ of saline on the right ear and saline only on the left ear. Inflammation was followed for $1 \mathrm{~h}$ and thereafter animals were killed by cervical dislocation. A $6 \mathrm{~mm}$ diameter disc from each ear was removed with a metal punch and weighed. The swelling induced by ovalbumin was assessed as the increase in the weight of the right ear punch biopsy over that of the left ear and was called the edema index.

\section{Determination of myeloperoxidase activity}

Tissue samples were assessed biochemically for the neutrophil marker enzyme myeloperoxidase (MPO), using the method of Bradley et al. $^{8}$ All the ear tissue was homogenized in $50 \mathrm{mM} \mathrm{K} \mathrm{HPO}_{4} / \mathrm{KH}_{2} \mathrm{PO}_{4}$ buffer (pH 6) containing $0.5 \%$ hexadecyl trimethylammonium bromide using a polytron (Ultra turrax $x$-25) homogenizer. After freeze-thawing three times, the samples were centrifuged at $2500 \times g$ for $30 \mathrm{~min}$ at $4^{\circ} \mathrm{C}$ and aliquots of the supernatant assayed spectrophotometrically for MPO. In brief, $40 \mu 1$ of sample was mixed with $960 \mu \mathrm{l}$ of $50 \mathrm{mM}$ phosphate buffer (pH 6) containing $0.167 \mathrm{mg} / \mathrm{ml}$ of $o$-dianisidine dihydrochloride and $0.0005 \%$ hydrogen peroxide. The change in absorbance at $460 \mathrm{~nm}$ was measured with a Spekol 220 spectrophotometer (Carl Zeiss, Germany). MPO activity data are presented as units per milligram of tissue. One unit of MPO activity was defined as that degrading one micromole of hydrogen peroxide to water per minute at $25^{\circ} \mathrm{C}$.

\section{Skin reactions to histamine and compound $48 / 80$ in rats}

The method described by Awouters et al. ${ }^{9}$ was used. Groups of five rats were pre-treated with phycocyanin (50, 100 and $200 \mathrm{mg} / \mathrm{kg}$ per-orally (p.o.)), saline and promethazine $(25 \mathrm{mg} / \mathrm{kg})$ as positive control.

One hour thereafter, the animals were injected by duplicate into the shaved dorsal skin with histamine $(50 \mu \mathrm{g})$ and the histamine releaser compound $48 / 80$ $(50 \mu \mathrm{g})$, and immediately afterwards also injected intravenously with $1 \mathrm{ml}$ of $0.4 \%$ Evans blue dye dissolved in saline.
After $30 \mathrm{~min}$, the rats were euthanized, skinned and the positive blue skin reactions were measured to determine their area.

\section{Histamine release from isolated rat peritoneal mast cells}

Experiments were performed using mixed peritoneal cells of the rat (1-5\% mast cells) prepared as described by Garland and Mongar. ${ }^{10}$

The peritoneal washings from at least five rats were pooled and kept on ice until used. The washings were centrifuged at $250 \times \mathrm{g}$ for $6 \mathrm{~min}$, the supernatant was discarded and the cell pellet resuspended in cold Tyrode solution ( $3 \mathrm{ml}$ per rat) of the following composition: $\mathrm{NaCl}, 137 \mathrm{mM} ; \mathrm{NaHCO}_{3}, 12 \mathrm{mM}$; $\mathrm{NaH}_{2} \mathrm{PO}_{4}, \quad 0.3 \mathrm{mM} ; \mathrm{KCl}, 2.7 \mathrm{mM} ; \mathrm{MgCl}_{2}, \quad 1 \mathrm{mM}$; $\mathrm{CaCl}_{2}, 1.8 \mathrm{mM}$; dextrose, $5.6 \mathrm{mM}$.

The cell suspension $(0.5 \mathrm{ml}$ aliquots in duplicate) was pre-incubated at $37^{\circ} \mathrm{C}$ for $10 \mathrm{~min}$ with three concentrations of phycocyanin $(3,5$ and $8 \mathrm{mg} / \mathrm{ml})$ and stimulated for a further $5 \mathrm{~min}$ with compound $48 / 80(1 \mu \mathrm{g} / \mathrm{ml})$. The reaction was then stopped by placing the tubes in an ice bath. Each sample was centrifuged at $250 \times g$ for $6 \mathrm{~min}$, the supernatant was decanted, and the pellets resuspended in $1 \mathrm{ml}$ of Tyrode solution and boiled for $10 \mathrm{~min}$ to release residual histamine. Release and residual histamine were measured fluorimetrically. ${ }^{11}$

The results are expressed as the percentage of histamine released from the total content of mast cells. Histamine release values were corrected for a spontaneous release of between 2 and $8 \%$. Preliminary assays demonstrated that phycocyanin did not interfere with fluorimetric histamine determination.

\section{Statistical analysis}

Data are presented as mean \pm SEM. Mean differences between groups were compared by one-way analysis of variance with the Duncan multi-range test. In experiments with rat peritoneal mast cells, Student's $t$-test was used to make a statistical comparison between the mean values. The level of statistical significance was taken as $p<0.05$.

\section{Results}

\section{Effects of phycocyanin on mouse ear swelling response to ovalbumin}

One hour after ovalbumin challenge, a marked increase in both ear thickness $(4.70 \pm 0.16 \mathrm{mg})$ and MPO activity $(3.13 \pm 0.21 \mathrm{U} / \mathrm{mg}$ of tissue) were observed in ovalbumin-sensitized mice (Table 1). Pretreatment with phycocyanin $(100,200$ and $300 \mathrm{mg} / \mathrm{kg}$ p.o.) $1 \mathrm{~h}$ before ovalbumin challenge significantly inhibited ear edema and MPO activity in this model. 
Table 1. Effect of phycocyanin on mouse ear swelling response to ovalbumin

\begin{tabular}{lccc}
\hline Treatment & $\begin{array}{c}\text { Edema index } \\
(\mathrm{mg})\end{array}$ & $\begin{array}{c}\text { Inhibition } \\
(\%)\end{array}$ & $\begin{array}{c}\text { MPO } \\
(\mathrm{U} / \mathrm{mg} \text { of tissue) }\end{array}$ \\
\hline Saline (non-sensitized) & $0.15 \pm 0.05^{*}$ & - & $0.14 \pm 0.05^{*}$ \\
Ovalbumin controls & $4.70 \pm 0.16^{*}$ & - & $3.13 \pm 0.21$ \\
Triamcinolone $(10 \mathrm{mg} / \mathrm{kg})$ & $0.25 \pm 0.05^{*}$ & 98 & $0.23 \pm 0.09^{*}$ \\
Phycocyanin $(100 \mathrm{mg} / \mathrm{kg})$ & $3.80 \pm 0.43^{*}$ & 19 & $2.45 \pm 0.46^{*}$ \\
Phycocyanin $(200 \mathrm{mg} / \mathrm{kg})$ & $2.28 \pm 0.19^{*}$ & 52 & $1.51 \pm 0.24^{*}$ \\
Phycocyanin $(300 \mathrm{mg} / \mathrm{kg})$ & $1.78 \pm 0.40^{*}$ & 62 & $1.07 \pm 0.14^{*}$ \\
\hline
\end{tabular}

Values are expressed as mean \pm SEM. Ten mice per group. The edema index was assessed as the increase in the weight of the right ear punch biopsy over that of the left ear. Edema was measured $1 \mathrm{~h}$ after ovalbumin challenge.

${ }^{*} p<0.05$, statistically significant with respect to ovalbumin control group.

The inhibitory effect of phycocyanin was dose dependent. Triamcinolone $(10 \mathrm{mg} / \mathrm{kg})$ also induced remarkable reduction on edema index and MPO activity (Table 1).

\section{Effect of phycocyanin on skin reactions} induced by intradermal injections of histamine and compound $48 / 80$ in rats

Pre-treatment with phycocyanin $(100$ and $200 \mathrm{mg} / \mathrm{kg}$ p.o.) significantly inhibited, in a dose-dependent manner, the skin reactions induced by compound $48 / 80$ and histamine. The lower dose of phycocyanin $(50 \mathrm{mg} / \mathrm{kg})$ did not induce significant inhibitory effect. The histamine $\mathrm{H}_{1}$-receptor antagonist promethazine $(25 \mathrm{mg} / \mathrm{kg})$ produced a strong inhibition of skin reaction induced by compound $48 / 80$ and histamine (Fig. 1).

\section{Effect of phycocyanin on histamine release from isolated rat peritoneal mast cells}

Phycocyanin $(3,5$, and $8 \mathrm{mg} / \mathrm{ml})$ significantly inhibited compound 48/80-induced histamine release from rat peritoneal mast cells following $10 \mathrm{~min}$ pre-incubation.

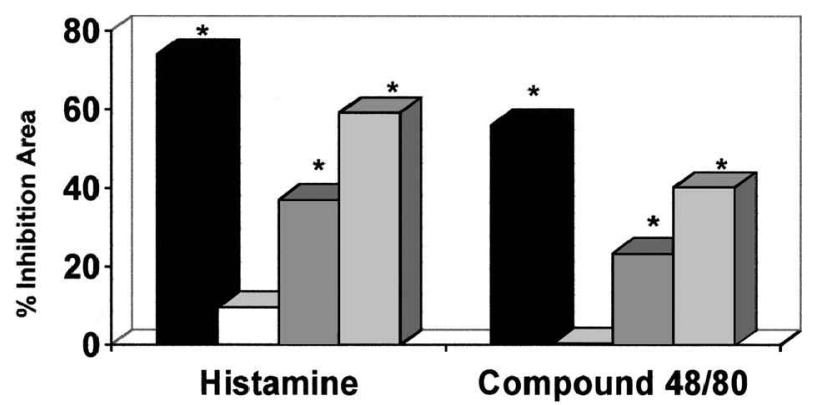

Dromethazine $\square$ Phycocyanin $100 \mathrm{mg} / \mathrm{kg}$

\section{$\square$ Phycocyanin $50 \mathrm{mg} / \mathrm{kg}$} $\square$ Phycocyanin $200 \mathrm{mg} / \mathrm{kg}$

FIG. 1. Effects of phycocyanin and promethazine on histamine and compound 48/80-induced cutaneous reactions in rats. Phycocyanin and promethazine were given orally $1 \mathrm{~h}$ before the challenge. Each value represents the mean of five animals. ${ }^{*} p<0.05$, statistically significant with respect to the controls (histamine and compound 48/80).
The inhibitory effect of phycocyanin was concentration dependent (Fig. 2).

\section{Discussion}

Increased microvascular permeability to plasma proteins is one of the characteristic features of the allergic inflammatory response. Mast cells are recognized to play a crucial role in allergen-induced plasma leakage because they can release pre-formed vasoactive mediators, among which the role of histamine and, in the case of rats and mice also of serotonin, has been historically emphasized. ${ }^{12,13}$

More recently, it has been demonstrated that, besides the former vasoactive amines, mast cells

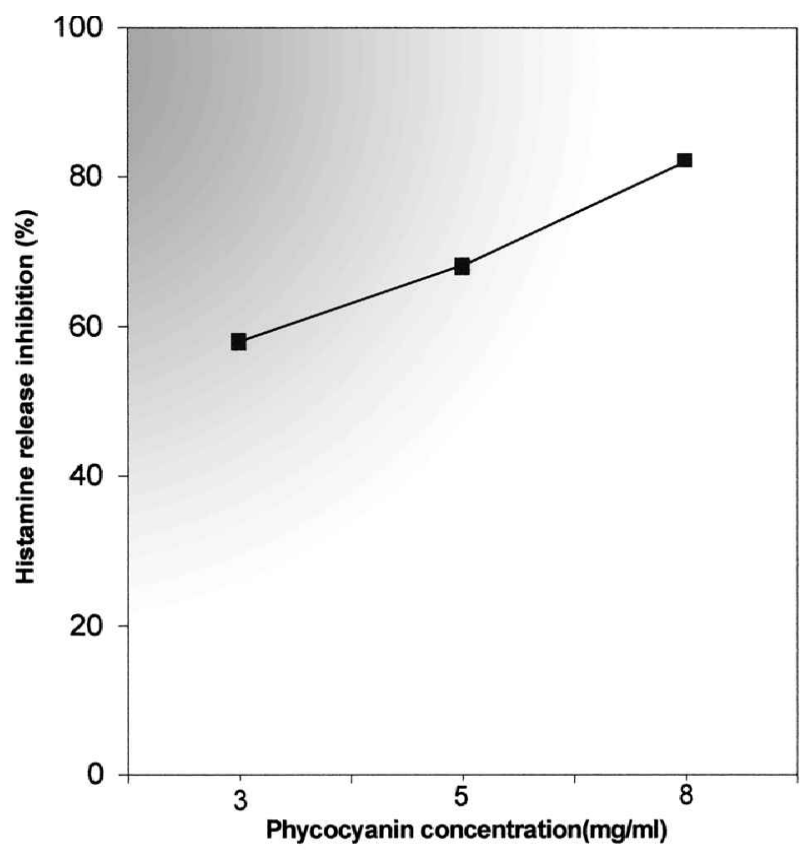

FIG. 2. Effect of phycocyanin on compound 48/80-induced histamine release from rat peritoneal mast cells. Rat peritoneal mast cells were pre-incubated at $37^{\circ} \mathrm{C}$ for $10 \mathrm{~min}$ with three different concentrations of phycocyanin and stimulated for a further $5 \mathrm{~min}$ with compound $48 / 80(1 \mu \mathrm{g} / \mathrm{ml})$. Each value is the mean \pm SEM of three experiments performed in duplicate. Significantly different from the control at $p<$ 0.05 . 
contain pre-formed stores of cytokines, such as tumor necrosis factor-alpha (TNF- $\alpha$ ) and vascular permeability factor/vascular endothelial cell growth factor among others, that can be released in immunoglobulin $\mathrm{E}$ (IgE)-dependent reactions and can provide a potential effector and immunoregulatory roles to mast cells in allergic inflammatory response. ${ }^{14}$ Also, it is important that the participation of the newly synthesized lipid mediators from mast cells such as prostaglandin $\mathrm{D}_{2}$, leukotrienes $\left(\mathrm{LTC}_{4}, \mathrm{LTD}_{4}, \mathrm{LTE}_{4}\right.$, $\mathrm{LTB}_{4}$ ) and platelet-activating factor (PAF), as well as ROS, are strongly involved in IgE-dependent allergic inflammation. ${ }^{14,15}$

In previous studies, we have demonstrated the antioxidant and anti-inflammatory properties of phycocyanin in various in vitro and in vivo experimental models. ${ }^{1,16-18}$ It was thus also shown that phycocyanin extract reduces $\mathrm{LTB}_{4}$ and prostaglandin $\mathrm{E}_{2}$ levels in the arachidonic acid-induced mouse ear inflammation test. ${ }^{2,3}$

In the present work, we have found that phycocyanin also exerts an anti-inflammatory effect in mouse ear swelling response to ovalbumin in which the various mediators quoted earlier are released in a IgEmediated reaction in sensitized mice (Table 1 ).

In this test, ear edema and MPO activity were reduced by phycocyanin. MPO is an enzyme present in neutrophils and at a much lower concentration in monocyte and macrophages. It is well known that the level of MPO activity is directly proportional to the neutrophil concentration on the inflamed tissue, ${ }^{8}$ by which measurement of the enzyme activity has been considered a quantitative and sensitive marker of chemotaxis and neutrophil infiltration in the inflammatory process. Therefore, the inhibitory effect of phycocyanin on MPO activity in ovalbumin-induced ear edema in mice constitutes further evidence of the anti-chemoattractant action of the biliprotein because previously we demonstrated that, in acetic acidinduced colitis in the rat, phycocyanin also reduced MPO activity in colonic tissue, and the histological findings also showed a substantial decrease in neutrophil infiltration in colonic mucosal injury. ${ }^{18}$

In our opinion the mechanism by which phycocyanin exerts its anti-chemoattractant action is through inhibitory effects on the biosynthesis of the neutrophil chemotactic mediator $\mathrm{LTB}_{4}$. This view is supported by our previous findings that phycocyanin reduced $\mathrm{LTB}_{4}$ levels in the arachidonic acid-induced mouse ear inflammation test. ${ }^{3}$

To elucidate whether phycocyanin is able to inhibit histamine release, we used the rat skin reaction test to histamine and compound $48 / 80$ as well as the in vitro method of histamine release induced by compound $48 / 80$ from isolated rat mast cells.

Promethazine (an $\mathrm{H}_{1}$-receptor antagonist), and to a lesser extent phycocyanin, inhibited skin reactions to histamine and compound 48/80, respectively (Fig. 1).
Through this observation, the possibility of phycocyanin or its metabolites interacting with $\mathrm{H}_{1}$-receptors must be considered, although this cannot be elucidated with this kind of experiment and will require further studies with the use of other methods such as radioligands.

On the contrary, the inhibitory effect of phycocyanin on histamine release from isolated rat mast cells (Fig. 2) supports the involvement of this event in the mode of action of the biliprotein as an anti-inflammatory agent, and particularly in the allergic reactions of the immediate type triggered by IgE.

At the present time, evidence is available that ROS such as superoxide anion, hydrogen peroxide, hydroxyl and peroxyl radicals may initiate the arachidonic acid cascade, PAF synthesis or histamine release. ${ }^{19-22}$ Thus, it has been demonstrated that ROS degranulate mast cells leading to release of histamine, serotonin, TNF- $\alpha$ and other mediators of inflammation. Furthermore, evidence has been provided that histamine is a marker of $\mathrm{OH}^{\bullet}$ radicals. ${ }^{23}$ Phycocyanin is able to scavenge hydroxyl, alkoxy and peroxyl radicals. ${ }^{1,24}$

Taking together the presented results, it is conceivable that these ROS scavenging properties of the biliprotein may explain its inhibitory effects on histamine release and other mediators of inflammation. However, further experiments are required to confirm whether ROS and other intracellular messengers such as cAMP and intracellular calcium ${ }^{25}$ might be involved in the inhibitory effect of phycocyanin on histamine release from rat mast cells.

\section{References}

1. Romay C, Armesto J, Remirez D, González R. Antioxidant and antiinflammatory properties of c-phycocyanin from blue-green algae. Inflamm Res 1998; 47: 36-41.

2. Romay C, Ledón N, González R. Effects of phycocyanin extract on prostaglandin $\mathrm{E}_{2}$ levels in mouse ear inflammation test. Arzneim Forsch/ Drug Res 2000; 50: 1106-1109.

3. Romay C, Ledón N, González R. Phycocyanin extract reduces leukotrienes $\mathrm{B}_{4}$ levels in arachidonic acid-induced mouse ear inflammation test. J Phar Pharmacol 1999; 51: 641-642.

4. Kim HM, Lee EH Cho H, Moon YH. Inhibitory effect of mast cellsmediated immediate type allergic reactions in rats by Spirulina. Biochem Pharmacol 1998; 55: 1071-1076.

5. Benitez F, Travieso L, Dupeiron R. Method for phycocyanin obtainment from microalgae. Cuban Patent Pending, RPI: 11/97.

6. Berns DS, MacColl R. Phycocyanin in physical-chemical studies. Chem Rev 1992; 89: 807-825.

7. Hessel EM, Van Oosterhout AJM, Hofstra CL. Bronchoconstriction and airways hyperresponsiveness after ovoalbumin inhalation in sensitized mice. Eur J Pharmacol 1995; 293: 401-412.

8. Bradley PP, Priebat DA, Chritensen RD, Rothstein G. Measurement of cutaneous inflammation: estimation of neutrophils content with an enzyme marker. J Invest Dermatol 1982; 78: 206-209.

9. Awouters F, Niemegeers CJE, Janssen PAJ. Interaction of astemizole and other drugs with PCA, histamine, serotonin and compound $48 / 80$-induced skin reactions in the rat A procedure to determine antiallergic effectiveness. Drug Dev Res 1985; 5: 137-145.

10. Garland LG, Mongar JL. Inhibition by cromoglycate of histamine release from rat peritoneal mast cells induced by mixtures of dextran, phosphatidyl serine and calcium ions. Br J Pharmacol 1974; 50: 137-143.

11. Shore PA, Burkhalter A, Cohn VN, A method for the fluorimetric assay of histamine in tissues. J Pharmacol Exp Ther 1959; 127: 182-186.

12. Halpern BN, Neveu T, Spector S. On the nature of the chemical mediators involved in anaphylactic reaction in mice. Br J Pharmacol 1963; 20: 389-398. 
13. Ohuchi K, Hirasawa N, Watanabe M, Tsurfuji S. Pharmacological analysis of the vascular permeability response in the anaphylactic phase of allergic inflammation in rats. Eur J Pharmacol 1985; 117: 337-345.

14. Williams CM, Galli SJ. The diverse potential effector and immunoregulatory roles of mast cells in allergic disease. J Allergy Clin Immunol 2000; 105: 847-859.

15. Fantozzi R, Brunelleschi S, Griuliattine L, et al. Mast cell and neutrophil interactions: a role for superoxide anion and histamine. Agents Actions 1985; 16: 260-264.

16. Romay C, Ledón N, González R. Further studies on anti-inflammatory activity of phycocyanin in some animal models of inflammation. Inflamm Res 1998; 47: 334-338.

17. Remirez D, González A, Merino N, Gonzalez $\mathrm{R}$, et al. Effect of phycocyanin in zymosan-induced arthritis in mice. Phycocyanin as an antiarthritic compound. Drug Dev Res 1999; 48: 70-75.

18. González R, Rodriguez S, Romay C. Anti-inflammatory activity of phycocyanin extract in acetic acid-induced colitis in rats. Pharmacol Res 1999; 39: 55-59.

19. Lewis MS, Whatley RE, Cain P. Hydrogen peroxide stimulates the synthesis of platelet activating factor by endothelium and induces endothelial celldependent neutrophil adhesion.J Clin Invest 1988; 82: 2045-2055.
20. Mannaioni PF, Masini E. The release of histamine by free radicals. Free Radic Biol Med 1988; 5: 177-197.

21. Masini E, Palmerani B, Gambassi F. Histamine release from rat mast cells induced by metabolic activation of polyunsaturated fatty acids into free radicals. Biochem Pharmacol 1990; 39: 879-889.

22. Alanko J, Riutta A, Mucha I. Modulation of arachidonic acid metabolism by phenols: relation to positions of hydroxyl groups and peroxyl radical scavenging properties. Free Radic Biol Med 1993; 14: 19-24.

23. Ching TL, Van der Hee RM, Bhoelan NM. Histamine as a marker for hydroxyl radicals. Mediat Inflamm 1995; 4: 339-343.

24. Lissi EA, Pizarro M, Aspee A. Kinetics of phycocyanin bilin groups destruction by peroxyl radicals. Free Radic Biol Med 2000; 28: 1051-1055.

25. Alfonso A, Cabado AG Vieytes MR. Functional compartments in rat mast cells for cAMP and calcium on histamine release. Cell Signal 2000; 12: $342-350$.

Received 25 September 2001

Accepted 21 January 2002 


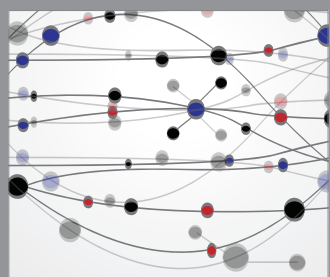

The Scientific World Journal
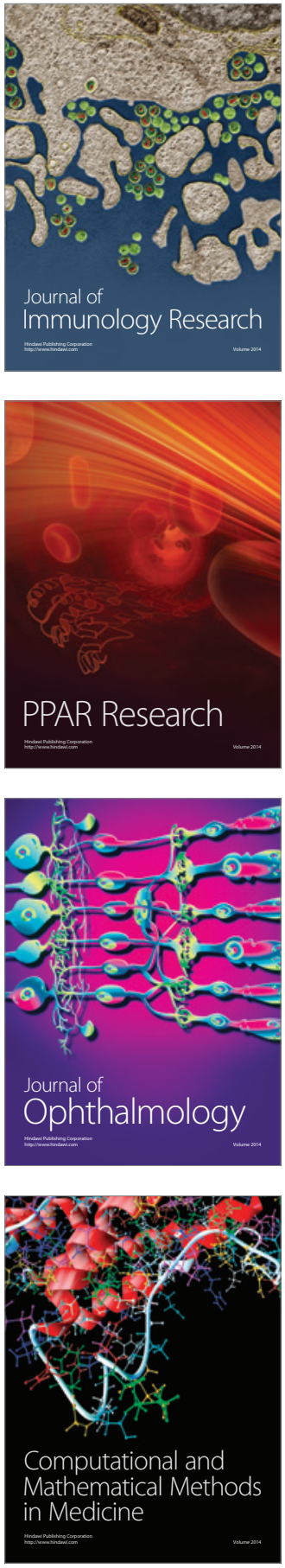

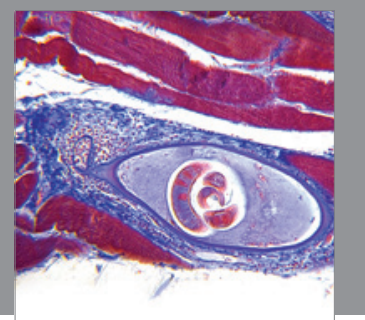

Gastroenterology

Research and Practice
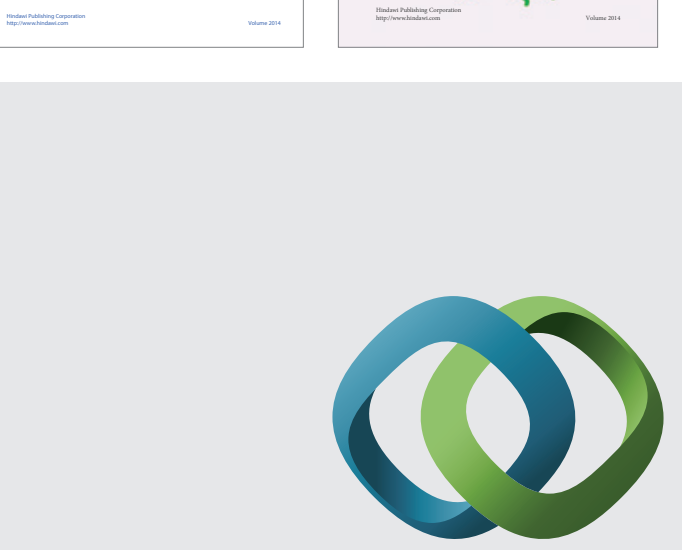

\section{Hindawi}

Submit your manuscripts at

http://www.hindawi.com
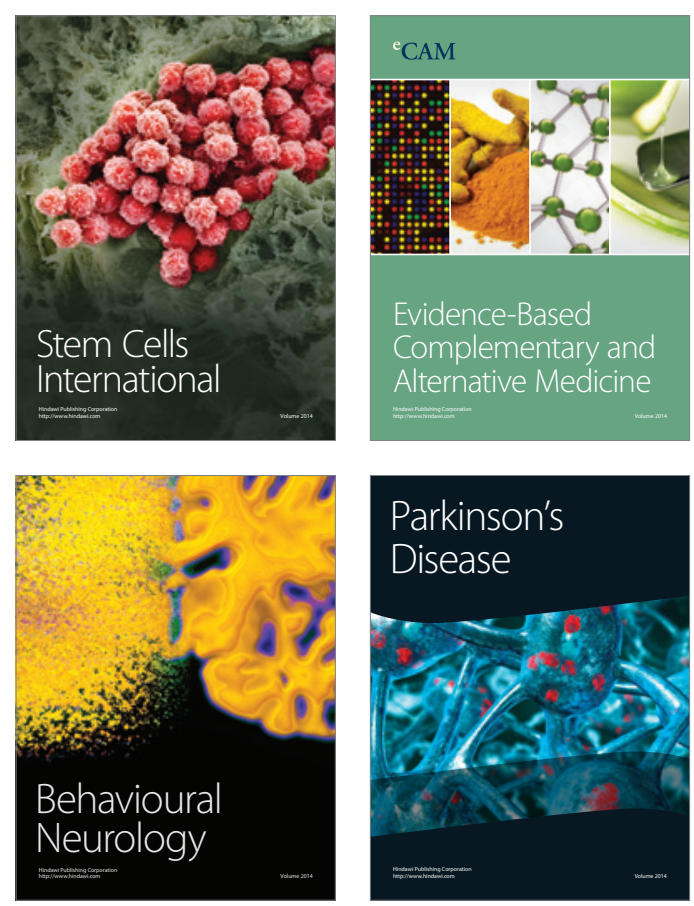

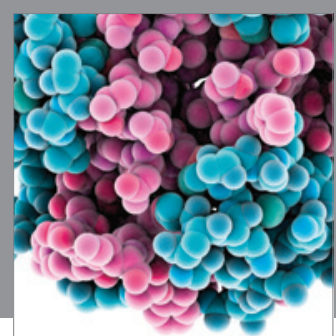

Journal of
Diabetes Research

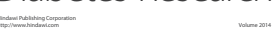

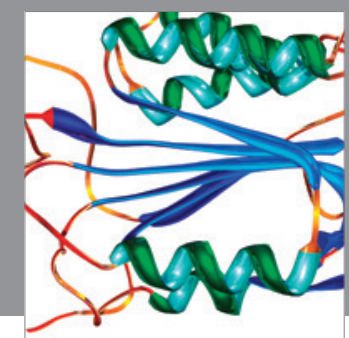

Disease Markers
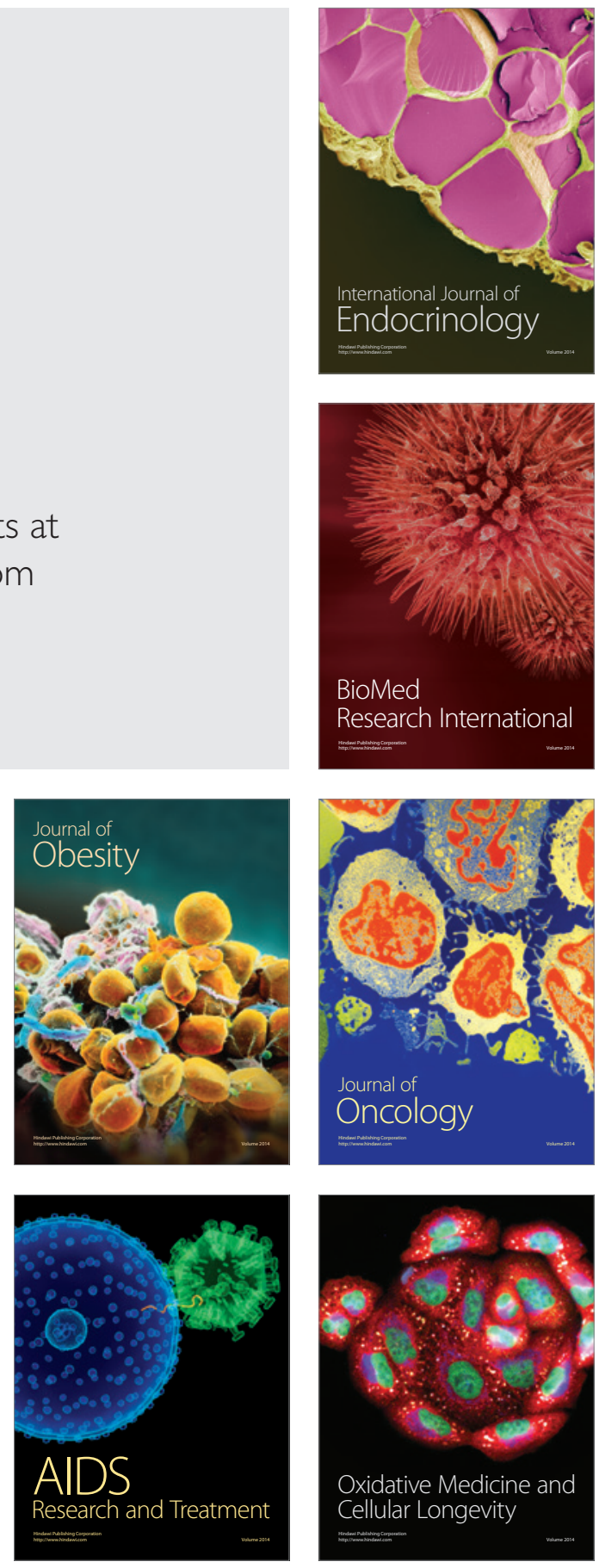